\title{
GnRH-II receptor-like antigenicity in human placenta and in cancers of the human reproductive organs
}

\author{
Nicola Eicke, Andreas R Günthert, Volker Viereck, Doreen Siebold, Martin Béhé ${ }^{1}$, Tamara Becker², Günter Emons \\ and Carsten Gründker \\ Department of Gynecology and Obstetrics, Georg-August-University, Robert-Koch-Street 40, D-37075 Göttingen, Germany, ${ }^{1}$ Department of Nuclear \\ Medicine, Philipps-University, Marburg, Germany and ${ }^{2}$ Department of Veterinary Medicine and Primate Husbandry, German Primate Center, Göttingen, \\ Germany \\ (Correspondence should be addressed to C Gründker; Email: grundker@med.uni-goettingen.de)
}

\begin{abstract}
We have recently demonstrated that the antiproliferative activity of GnRH-II on human endometrial and ovarian cancer cell lines is not mediated through the GnRH-I receptor. A functional receptor for human GnRH-II has not yet been identified. In this study, we have generated a polyclonal antiserum to the putative human GnRH-II receptor using a peptide (YSPTMLTEVPPC) corresponding to the third extracellular domain coupled to keyhole limpet haemocyanin via the Cys residue. A database search showed no identical peptide sequences in any other human gene. To avoid cross-reactions against two similar amino acid sequences the antiserum was pre-absorbed using these peptides. Immune histological sections of human placenta and human endometrial, ovarian and prostate cancers using rabbit anti-human GnRH-II receptor antiserum showed GnRH-II receptor-like staining. Western blot analysis of cell membrane preparations of human endometrial and ovarian cancer cell lines yielded a band at approximately $43 \mathrm{kDa}$ whereas Western blot analysis of cell membrane preparations of ovaries obtained from the marmoset monkey (Callithrix jacchus) yielded a band at approximately $54 \mathrm{kDa}$. To identify the GnRH-II receptor-like antigen we used the photo-affinity labelling technique. Photochemical reaction of ${ }^{125}$ I-labelled (4-azidobenzoyl)-N-hydroxysuccinimide-[D-Lys ${ }^{6}$ ]-GnRH-II $\left(10^{-9} \mathrm{M}\right)$ with cell membrane preparations of human endometrial and ovarian cancer cells yielded a band at approximately $43 \mathrm{kDa}$. In competition experiments, the GnRH-I agonist Triptorelin $\left(10^{-7} \mathrm{M}\right)$ showed a weak decrease of ${ }^{125}$ I-labelled (4-azidobenzoyl)-N-hydroxysuccinimide-[D-Lys ${ }^{6}$ ]GnRH-II binding to its binding site. The GnRH-I antagonist Cetrorelix $\left(10^{-7} \mathrm{M}\right)$ showed a clearly stronger decrease, whereas GnRH-II agonist [D-Lys $\left.{ }^{6}\right]$-GnRH-II $\left(10^{-7} \mathrm{M}\right)$ was the most potent competitor. Western blot analysis of the same gel using rabbit anti-human GnRH-II receptor antiserum identified this band as GnRH-II receptor-like antigen.
\end{abstract}

European Journal of Endocrinology 153 605-612

\section{Introduction}

The expression of gonadotrophin-releasing hormone type I (GnRH-I) and its receptor as a part of a negative autocrine/paracrine regulatory system of cell proliferation has been demonstrated in a number of human malignant tumours, including cancers of the human reproductive organs (1). In these cancers, the in vitro proliferation can be inhibited by agonistic and/or antagonistic analogues of GnRH-I in a dose- and time-dependent manner (1-5). The dichotomy of GnRH-I agonists and antagonists as defined in pituitary gonadotrophs might not apply to the GnRH system in cancer cells.

GnRH type II (GnRH-II) has antiproliferative effects on these tumour cells which are significantly greater than those of the superactive GnRH-I agonist Triptorelin (6). In the ovarian cancer cell line SK-OV-3, which does not express GnRH-I receptors (7), the GnRH-I agonist Triptorelin had no effects on cell proliferation (7), whereas the GnRH-I antagonist Cetrorelix and GnRHII had strong antiproliferative effects. We have recently shown that in cell lines affected by both the GnRH-I agonist Triptorelin and the GnRH-I antagonist Cetrorelix, the effects of the former were abrogated after GnRHI receptor knockout, whereas those of Cetrorelix and of GnRH-II persisted (8). These findings suggested that the antiproliferative effects of the GnRH-I antagonist Cetrorelix and of GnRH-II are not mediated through the GnRH-I receptor. Our data are in agreement with a report from Enomoto et al. (9) demonstrating that the human GnRH-II receptor is functional, and that 
its splice variant determines the direction of the cellular response to GnRH stimulation. Choi et al. (10) have reported that the ligand (GnRH-II) is expressed in normal neoplastic ovarian surface epithelial cells and in cancers derived from these cells. In addition, they showed that, in immortalized ovarian surface epithelial cells, GnRH-II had antiproliferative effects (10). It might be speculated that, in addition to the autocrine GnRH-I system, an additional autocrine system based on GnRH-II exists in human cancers.

Several groups have tried to find a functional human GnRH-II receptor transcript (11-14). Until now, attempts to clone and sequence a full-length human GnRH-II receptor have not been successful (15). Morgan et al. (16) found that the human GnRH-II receptor is expressed as a variety of splice variants and a functional human GnRH-II receptor transcript was not found. The GnRH-II receptor-like mRNA detected in our previous studies $(6,8)$ is suspected to be non-functional because of the stop codon in the sequence (15). Nevertheless, the data of the knockout experiments suggested that in human endometrial and ovarian cancer cells, in addition to the GnRH-I receptor, an additional functional receptor may be present, mediating the antiproliferative effects of the GnRH-I antagonist Cetrorelix and GnRH-II (8).

In this study we have assessed whether or not a $\mathrm{GnRH}-\mathrm{II}$ receptor protein exists in human reproductive organs. For this purpose we have generated a polyclonal antiserum to the putative human GnRH-II receptor as described by Millar et al. (11). To identify the GnRHII receptor-like antigen we used the photo-affinity labelling technique.

\section{Materials and methods}

\section{Cell lines and culture conditions}

The human endometrial cancer cell lines Ishikawa and HEC-1A and the ovarian cancer cell lines EFO-21, EFO27 and SK-OV-3 were obtained from American Type Culture Collection (Manassas, VA, USA) or the sources detailed previously $(2,3)$. The cells were cultured at $37^{\circ} \mathrm{C}$ in a humidified atmosphere of $5 \% \mathrm{CO}_{2}$ in air as previously described $(2-4)$.

\section{GnRH analogues}

The GnRH-I antagonist Cetrorelix (SB-75; [Ac$\left.\left.\operatorname{DNal}(2)^{1}, \mathrm{D}-\mathrm{Phe}(4 \mathrm{Cl})^{2}, \mathrm{D}-\mathrm{Pal}(3)^{3}, \mathrm{D}-\mathrm{Cit}^{6}, \mathrm{D}-\mathrm{Ala}{ }^{10}\right]-\mathrm{GnRH}-\mathrm{I}\right)$ was kindly provided by Zentaris (Frankfurt, Germany) and the GnRH-I agonist [D-Trp $\left.{ }^{6}\right]-G n R H-I$ (Triptorelin; pGlu-His-Trp-Ser-Tyr-D-Trp-Leu-Arg-Pro-Gly- $\mathrm{NH}_{2}$ ) was kindly provided by Ferring Pharmaceuticals (Copenhagen, Denmark). The GnRH-II agonist [D-Lys ${ }^{6}$ ]-GnRH-II (pGlu-His-Trp-Ser-His-D-Lys-Trp-TyrPro-Gly- $\mathrm{NH}_{2}$ ) was synthesized by Peptide Speciality Laboratories (Heidelberg, Germany). The azidobenzoyl derivate of $\left[\mathrm{D}^{-\mathrm{Lys}^{6}}{ }^{6}\right]-\mathrm{GnRH}-\mathrm{II}$ was prepared by the method of Hazum (17). [D-Lys ${ }^{6}-\mathrm{N}^{\epsilon}$-azidobenzoyl]GnRH-II was labelled with ${ }^{125}$ I using the lactoperoxidase method of Clayton et al. (18) and purified by HPLC.

\section{Tissues}

Ovaries from marmoset monkeys (Callithrix jacchus) were collected from normal healthy animals during ovariectomy.

To localize GnRH-II receptor-like antigenicity in sections of human placenta (gestational age: week 25) and of malignant tumours of human reproductive organs we used human tissue arrays (SuperBioChips Laboratories, Yongdu-Dong, Korea) containing paraffin-embedded human normal and malignant tissues.

Written, informed consent for the use of human tissues was given.

\section{Membrane preparations}

Cells were collected by centrifugation at $200 \boldsymbol{g}$ and washed twice with phosphate-buffered saline (PBS)/bovine serum albumin (BSA). After counting the aliquots, cells were suspended and homogenized using an all-glass Potter homogenizer (Braun, Melsungen, Germany) in $10 \mathrm{mmol} / \mathrm{l}$ Tris-HCl buffer, $\mathrm{pH}$ 7.6, containing $2 \mathrm{~g} \mathrm{BSA} / \mathrm{l}, 2 \mathrm{~g} \mathrm{NaN}_{3} / \mathrm{l}$ and $1 \mathrm{mmol} / \mathrm{l}$ dithiothreitol (DTT) (Merck \& Co., Darmstadt, Germany). After removing nuclei and debris by centrifugation at $200 \boldsymbol{g}$, plasma membranes were collected at $70000 \mathbf{g}$. Aliquots of the membrane preparations, equivalent to 300000-400000 cells, were resuspended in lysis buffer $(1 \mathrm{mmol} / \mathrm{l}$ EGTA, $1 \mathrm{mmol} / \mathrm{l}$ DTT and $10 \mathrm{mmol} / \mathrm{l}$ Tris- $\mathrm{HCl}, \mathrm{pH}$ 7.4).

\section{Anti-human GnRH-II receptor antiserum}

Two rabbits were immunized with $2 \mathrm{mg}$ of a peptide (YSPTMLTEVPPC) corresponding to the third extracellular domain coupled to keyhole limpet haemocyanin via the Cys residue in complete Freund's adjuvant followed by three individual boosters at 3-week intervals in incomplete Freund's adjuvant. Blood was collected by heart puncture (Peptide Speciality Laboratories).

Between the boosters and especially before the bleeding a small amount of blood was tested against ovalbumin-conjugated peptide to determine the titre of the corresponding serum.

The antiserum was pre-absorbed using LTEVPP and PSMATEAPPC to avoid possible cross-reactions.

\section{Immune histology}

Ovaries from marmoset monkeys were fixed using $4 \%$ paraformaldehyde in PBS at $4{ }^{\circ} \mathrm{C}$ overnight, dehydrated and embedded in paraffin. Sections of $4 \mu \mathrm{m}$ thickness 
were then prepared and put on silane-coated slides. These slides or the tissue array slides were deparaffinized and rehydrated. Antigens were retrieved by incubation with $0.01 \mathrm{M}$ citrate buffer $(\mathrm{pH}$ 6.0) in a microwave $(700 \mathrm{~W})$ for $5 \mathrm{~min}$. Endogenous peroxidase activity was quenched by treatment with $3 \%$ hydrogen peroxide solution for $6 \mathrm{~min}$. After washing in PBS, the slides were treated with polyclonal rabbit anti-human GnRH-II receptor antiserum in a 1:10000 dilution in $1 \%$ BSA in $10 \mathrm{~mm}$ Tris, $\mathrm{pH} 8.0,500 \mathrm{~mm} \mathrm{NaCl}$ and $0.1 \%$ Tween 20 (TBST) for $1 \mathrm{~h}$ and, after being washed, were detected with the ready-to-use secondary antibody horseradish peroxidase-conjugated anti-rabbit IgG detection system according to the instructions of the supplier (Zymed Laboratories, San Francisco, CA, USA). Controls were perfomed by substitution of the primary antiserum with pre-immune serum of the same rabbit.

Counterstaining was performed using Meyer's haematoxylin for $10 \mathrm{~s}$. The slides were then dehydrated, cleared, mounted with Permount and studied by light microscopy.

The experiments using tissue array slides were repeated three times and the experiments using ovaries from marmoset monkeys were repeated four times using four different ovaries obtained from two different animals.

\section{Western blotting}

Cell membranes were electrophoresed on SDS-PAGE $(7.5 \%)$ under reducing conditions and transferred to nitrocellulose. The nitrocellulose membranes were blocked in 3\% BSA (Sigma) in TBST for $2 \mathrm{~h}$, incubated with polyclonal rabbit anti-human GnRH-II receptor antiserum in a 1:500 dilution in 1\% BSA in TBST for $1 \mathrm{~h}$ and then, after washing, incubated with horseradish peroxidase-conjugated anti-rabbit IgG (Amersham Pharmacia Biotech, Amersham, Bucks, UK) in a 1:10000 dilution in 1\% BSA in TBST for $1 \mathrm{~h}$. After washing, specifically bound antibody was detected using the enhanced chemiluminescence kit (Amersham Pharmacia Biotech).

The data were obtained from three independent experiments run in duplicate in three different passages of each cell line. The experiments using ovaries from marmoset monkeys were repeated four times using four different ovaries obtained from two different animals.

\section{Photo-affinity labelling}

Tumour cells were incubated in $1 \mathrm{ml}$ binding buffer (25 mM Tris-HCl, pH 7.4, $5 \mathrm{mM} \mathrm{MgCl} 2,100 \mathrm{mM} \mathrm{NaCl}$, $1 \%$ BSA and $0.01 \%$ bacitracin) containing $0.01 \%$ soybean trypsin inhibitor and the photoreactive radioligand ${ }^{125}$ I-labelled $\left[\mathrm{D}\right.$-Lys ${ }^{6}-\mathrm{N}^{\epsilon}$-azidobenzoyl]GnRH-II $\left(10^{-9} \mathrm{M}\right)$, in the presence or absence of unlabelled [D-Lys $\left.{ }^{6}\right]-G n R H-I I \quad\left(10^{-7} \mathrm{M}\right), \quad$ unlabelled Cetrorelix $\left(10^{-7} \mathrm{M}\right)$ or unlabelled Triptorelin $\left(10^{-7} \mathrm{M}\right)$. After $1 \mathrm{~h}$ at room temperature, cells were washed with $20 \mathrm{ml}$ ice-cold washing buffer $(25 \mathrm{mM}$ Tris-HCl, pH $7.4,5 \mathrm{mM} \mathrm{MgCl}_{2}$ and $100 \mathrm{mM} \mathrm{NaCl}$ ) and irradiated at $0{ }^{\circ} \mathrm{C}$ for $10 \mathrm{~min}$ at $25 \mathrm{~cm}$ distance with a $254 \mathrm{~nm} 6 \mathrm{~W}$ lamp. Cells were then gently scraped and centrifuged at $200 \mathrm{~g}$ for $10 \mathrm{~min}$ at $4^{\circ} \mathrm{C}$. The pellet was solubilized in a buffer containing $100 \mathrm{mM} \mathrm{Na} \mathrm{HPO}_{4}$, pH 8.5, $25 \mathrm{mM}$ EDTA, $0.1 \mathrm{mg} / \mathrm{ml}$ soybean trypsin inhibitor and $1 \%$ (v/v) Nonidet P-40. The solubilized photolabelled receptors were diluted with an equal volume of $2 \times$ loading buffer (120 mM Tris-HCl, pH 6.8, 20\% (v/v) glycerol, $4 \%(\mathrm{w} / \mathrm{v})$ SDS, $200 \mathrm{mM}$ DTT and $0.05 \%(\mathrm{w} / \mathrm{v})$ bromophenol blue) and boiled for $5 \mathrm{~min}$. SDS-PAGE was performed as described by Laemmli (19) using $1.5 \mathrm{~mm}$ $10 \%$ gels. The gels were dried and exposed to an X-ray film with an intensifying screen.

The data were obtained from three independent experiments run in duplicate in three different passages of each cell line.

\section{Results}

\section{GnRH-II receptor in the ovary of the marmoset monkey}

A specific antiserum to the third extracellular domain of the type II GnRH receptor demonstrated specific expression of the receptor in immune histological sections of ovaries obtained from marmoset monkeys (Fig. 1A). The most intensive staining was shown in the surface epithelium of the ovary (Fig. 1A). Controls performed by substitution of the primary antiserum
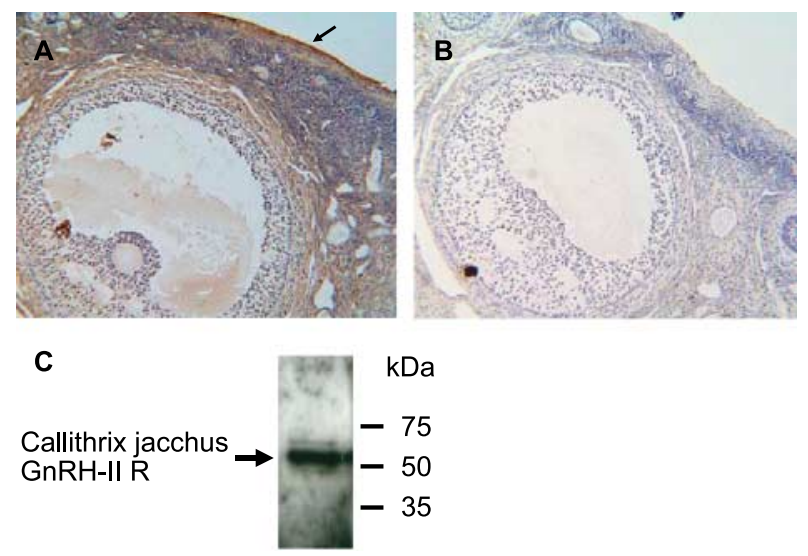

Figure $1 \mathrm{GnRH}-\mathrm{Il}$ receptor expression in the ovary of marmoset monkeys. (A) Immune histochemical localization of $\mathrm{GnRH}$-II receptor antigenicity in ovaries obtained from marmoset monkeys. The most intensive staining was shown in the surface epithelium of the ovary (arrow). (B) Controls performed by substitution of the primary antiserum with pre-immune serum of the same rabbit showed no staining. (C) Western blot analysis of cell membrane preparations of ovaries obtained from marmoset monkeys under reducing conditions yielded a band at approximately $54 \mathrm{kDa}$. 
with pre-immune serum of the same rabbit showed no staining (Fig. 1B). Western blot analysis of cell membrane preparations of ovaries obtained from marmoset monkeys yielded a band at approximately $54 \mathrm{kDa}$ (Fig. 1C). To avoid possible cross-reactions with the similar amino acid sequences LTEVPP and PSMATEAPPC the antiserum was pre-absorbed using these peptides. Thereafter most unspecific bands were eliminated. After precipitation of the antiserum with the peptide (YSPTMLTEVPPC) used for immunization of the rabbits, no specific staining could be observed any more indicating the specificity of the antiserum (not shown).

\section{GnRH-II receptor-like antigenicity in human placenta and in cancers of the human reproductive organs}

Immune histological sections of human placenta (Fig. 2A) and human endometrial (Fig. 2B), ovarian (Fig. 2C) and prostate (Fig. 2D) cancers using the above-mentioned antiserum showed GnRH-II receptorlike staining. Controls performed by substitution of the primary antiserum with pre-immune serum of the same rabbit showed no staining (not shown). All cells of the placental chorionic epithelium showed GnRH-II receptor-like antigenicity (Fig. 2A). Note the strong staining on the luminal surface of the cells (Fig. 2A, arrows). Figure 2B shows an endometrial adenocarcinoma. All epithelial cells showed GnRH-II receptorlike antigenicity. However, some cells were much more positive for GnRH-II receptor-like staining than others (Fig. 2B, arrows). Figure 2C shows a mucinous
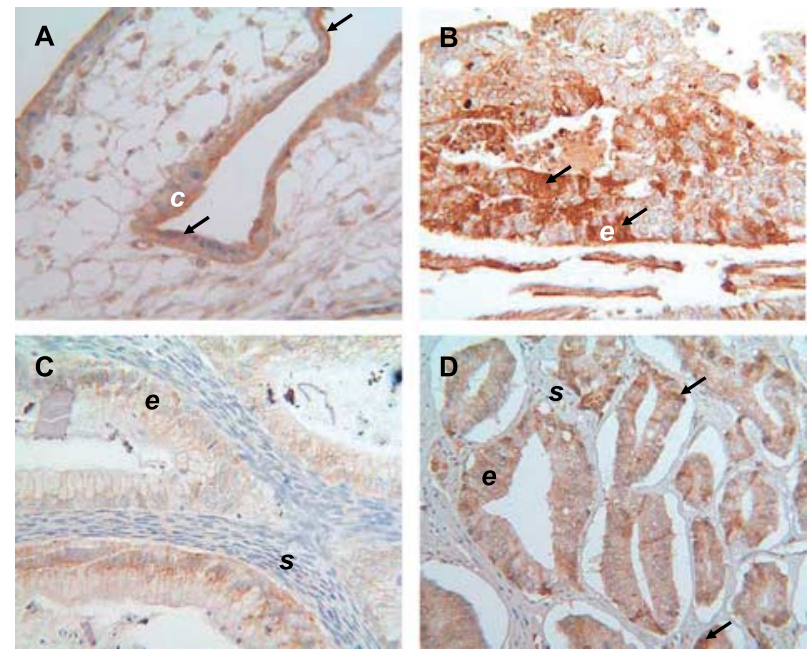

Figure 2 Immune histochemical localization of $\mathrm{GnRH}$-II receptorlike antigenicity in sections of (A) human placenta (gestational age: week 25), (B) a human endometrial adenocarcinoma, (C) a human mucinous cystadenocarcinoma of the ovary and (D) a human prostate adenocarcinoma. $c$, chorionic epithelial cells; $s$, stromal cells; $e$, epithelial cells. The experiment was repeated three times. cystadenocarcinoma of the ovary. All epithelial cells were positive for the GnRH-II receptor-like antigen. The stroma showed only a very slight background staining. Figure 2D shows a prostate adenocarcinoma. All epithelial cells but not the stroma cells showed strong GnRH-II receptor-like antigenicity. Some cells were much more positive for GnRH-II receptor-like staining than others (Fig. 2D, arrows)

Western blot analysis of cell membrane preparations of human endometrial (Fig. 3A and B) and ovarian (Fig. 3C and D) cancer cell lines yielded a band at approximately $43 \mathrm{kDa}$ whereas Western blot analysis of cell membrane preparations of ovaries obtained from marmoset monkeys yielded a band at approximately $54 \mathrm{kDa}$ as shown on the same blot (Fig. 3E). Western blot analysis of the human ovarian cancer cell line EFO-27 and of human placenta showed a much weaker band at $43 \mathrm{kDa}$ (not shown). Using the same quantity of protein, the GnRH-II receptor-like protein seemed to be much more expressed in marmoset monkeys. To detect a similar intensity of the bands within the Western blot, 40-fold higher protein quantities of the human cancer cell lines were needed.

\section{Identification of the human GnRH-II receptor-like antigen}

To identify the GnRH-II receptor-like antigen we used the photo-affinity labelling technique. Photochemical reaction of ${ }^{125}$ I-labelled (4-azidobenzoyl)-N-hydroxysuccinimide-[D-Lys $\left.{ }^{6}\right]$-GnRH-II with cell membrane preparations of human ovarian cancer cell lines EFO21 and SK-OV-3 yielded a band at approximately $43 \mathrm{kDa}$ (Fig. 4A). The human ovarian cancer cell line EFO-27 showed only an extremely weak signal (Fig. 4A). Western blot analysis of the same gel using rabbit anti-human GnRH-II receptor antiserum identified this band as GnRH-II receptor-like antigen (Fig. 4B). Experiments using the human endometrial cancer cell lines Ishikawa and $\mathrm{Hec}-1 \mathrm{~A}$ gave results comparable with those shown for the EFO-21 and SK-



Figure $3 \mathrm{GnRH}-$ II receptor $(\mathrm{R})$-like protein expression in cell membrane preparations of human endometrial cancer cell lines (A) Ishikawa and (B) Hec-1A and human ovarian cancer cell lines (C) EFO-21 and (D) SK-OV-3. (E) GnRH-II receptor protein expression in cell membrane preparations of ovaries obtained from marmoset monkeys. The data were obtained from three independent experiments run in duplicate in three different passages of each cell line. The experiments using ovaries from marmoset monkeys were repeated four times using four different ovaries obtained from two different animals. 


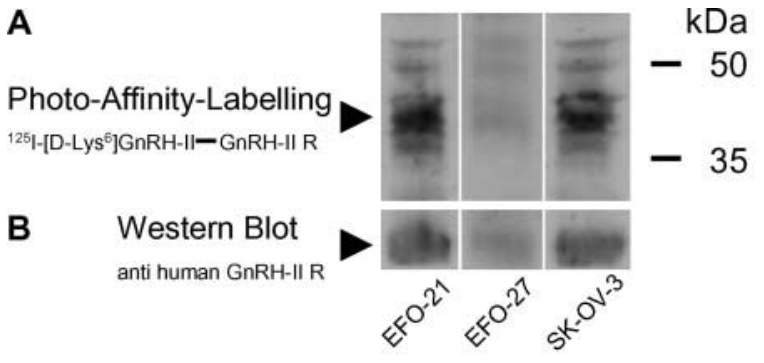

C

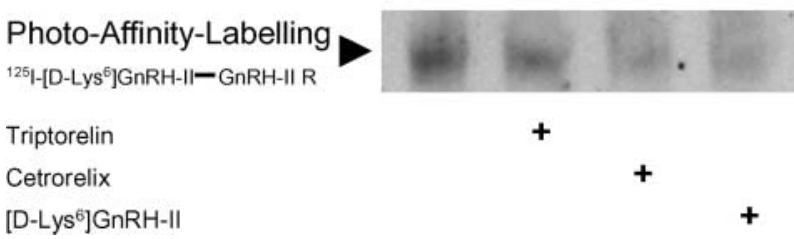

Figure 4 (A) Photo-affinity labelling of GnRH-II-binding sites in human ovarian cancer cell lines EFO-21, EFO-27 and SK-OV-3 using photoreactive radioligand ${ }^{125} \mathrm{I}-\left[\mathrm{D}-\mathrm{Lys}^{6}-\mathrm{N}^{\epsilon}\right.$-azidobenzoyl]$\mathrm{GnRH}-\mathrm{II}\left(10^{-9} \mathrm{M}\right)$. After photo labelling, cellular proteins were solubilized, denatured and submitted to SDS-PAGE on a $10 \%$ acrylamide separating gel ( $40 \mu \mathrm{g}$ protein/lane) followed by autoradiography. (B) Western blot analysis of the same gel using rabbit anti-human $\mathrm{GnRH}-\mathrm{II}$ receptor antiserum. Experiments using the human endometrial cancer cell lines Ishikawa and Hec-1A gave results comparable with those shown for the EFO-21 and SK-OV-3 human ovarian cancer cell lines. (C) Competition experiment using the human ovarian cancer cell line EFO-21 with a 100 -fold excess of unlabelled $\mathrm{GnRH}-\mathrm{I}$ agonist Triptorelin $\left(10^{-7} \mathrm{M}\right)$, unlabelled $\mathrm{GnRH}-\mathrm{I}$ antagonist Cetrorelix $\left(10^{-7} \mathrm{M}\right)$ or unlabelled $\mathrm{GnRH}-\mathrm{Il}$ agonist $\left[\mathrm{D}-\mathrm{Lys} \mathrm{s}^{6}\right]-\mathrm{GnRH}-\mathrm{II}\left(10^{-7} \mathrm{M}\right)$. The data were obtained from three independent experiments run in duplicate in three different passages of each cell line.

OV-3 human ovarian cancer cell lines (not shown). Experiments using human placenta gave results comparable with those shown for the EFO-27 cell line (not shown).

Competition experiments with an excess of unlabelled GnRH-I agonist Triptorelin, unlabelled GnRH-I antagonist Cetrorelix or unlabelled GnRH-II agonist [D-Lys ${ }^{6}$-GnRH-II suggested that all three substances were able to displace the ${ }^{125}$ I-labelled (4-azidobenzoyl)-N-hydroxysuccinimide-[D-Lys ${ }^{6}$ ]-GnRH-II, but in a different strength (Fig. 4C). A 100-fold excess of the GnRH-I agonist Triptorelin showed a weak decrease of binding of ${ }^{125}$ I-labelled (4-azidobenzoyl)-N-hydroxysuccinimide-[D-Lys $\left.{ }^{6}\right]-G n R H-I I$ to its binding site. A 100-fold excess of the GnRH-I antagonist Cetrorelix showed a clearly stronger decrease, whereas a 100fold excess of GnRH-II agonist [D-Lys ${ }^{6}$ ]-GnRH-II was the most potent competitor (Fig. 4C).

\section{Discussion}

We have previously demonstrated that, in human endometrial and ovarian cancer cell lines affected by the GnRH-I agonist Triptorelin, the GnRH-I antagonist Cetrorelix and GnRH-II agonist [D-Lys ${ }^{6}$-GnRH-II, the effects of Triptorelin were abrogated after GnRH-I receptor knockout, whereas those of Cetrorelix and [D-Lys ${ }^{6}$ GnRH-II persisted (8). These findings suggested that the antiproliferative effects of the GnRH-I antagonist Cetrorelix and GnRH-II agonist [D-Lys ${ }^{6}$ ]-GnRH-II are not mediated through the GnRH-I receptor (8).

Several groups have tried to find a functional human GnRH-II receptor transcript (11-14). Until now, attempts to clone and sequence the full-length human GnRH-II receptor have not been successful (14). However, our previously demonstrated data (8) suggest that in human endometrial and ovarian cancer cells, in addition to the GnRH-I receptor, another functional receptor may be present mediating the antiproliferative effects of the GnRH-I antagonist Cetrorelix and of GnRH-II agonist [D-Lys ${ }^{6}$ ]-GnRH-II. These results are in accord with a report from Enomoto et al. (9).

In this study we were able to show the first clear evidence for the existence of a GnRH-II receptor-like protein in human placenta and in cancers of the human reproductive organs. For this purpose, we have generated a polyclonal antiserum to the putative human GnRH-II receptor using a peptide (YSPTMLTEVPPC) corresponding to the third extracellular domain coupled to keyhole limpet haemocyanin via the Cys residue as described by Millar et al. (11). Although the 12 amino acid sequence is unique in the putative GnRH-II receptor, six of the amino acids of this sequence, LTEVPP, are expressed in RLIM transcription factor, a RING $\mathrm{H} 2$ zinc finger protein. Thus the immune histological data of Millar et al. (11) have been interpreted as a possible non-specific finding (20). The GnRH-II receptor antiserum could be reacting with this six amino acid sequence. A second similar peptide sequence, PSMATEAPPC, is expressed in the human membrane protein protease inhibitor 16 and cross-reaction with this epitope would affect the interpretation of our results. Since the antiserum was pre-absorbed using LTEVPP and PSMATEAPPC possible cross-reactions should have been eliminated.

The antiserum to the GnRH-II receptor was tested on sections of ovaries obtained from marmoset monkeys and on Western blots of cell membrane preparations of ovaries obtained from marmoset monkeys. The Western blot analysis yielded a band at approximately $54 \mathrm{kDa}$. After precipitation of the antiserum with the antigen used for immunization of the rabbits, no staining could be observed any more. This indicated that the antiserum is specific to the GnRH-II receptor. The molecular weight of the non-glycosylated form of the marmoset monkey GnRH-II receptor is approximately $42 \mathrm{kDa}(21)$. The shift to approximately $54 \mathrm{kDa}$ might represent the addition of carbohydrate.

Immune histological sections of human placenta and human endometrial, ovarian and prostate cancers using the above-characterized rabbit antihuman GnRH-II receptor antiserum showed GnRH-II 
receptor-like staining, indicating the existence of a GnRH-II receptor-like protein in these human tissues. Western blot analysis of cell membrane preparations of human endometrial and ovarian cancer cell lines yielded a band at approximately $43 \mathrm{kDa}$. It is possible that this $43 \mathrm{kDa}$ band represents a shorter variant of the GnRHII receptor with five transmembrane domains (5TM domain human GnRH-II receptor) at a comparable glycosylation status as the marmoset monkey GnRH-II receptor. As demonstrated by Neill et al. (22), all considerations lead to the conclusion that if a functional GnRH-II receptor is expressed in human tissues it may be a 5TM domain receptor lacking TM regions I and II. A precedent for this hypothesis is the report of a functional 5TM receptor lacking these TM regions (23). The complexities and potential roles of the disrupted human GnRH-II receptor gene homologue have been extensively debated and discussed (for review see 22). Neill et al. (22) also discussed emerging evidence for the existence of a functional GnRH-II receptor in the human and suggest the possibility that protein fragments derived from the disrupted human GnRH-II gene homologue may associate with one another or with the human GnRH-I receptor to produce a functional GnRH-II responsive receptor. However, it is also possible that the $43 \mathrm{kDa}$ band represents the full-length GnRH-II receptor at a different glycosylation status. Since 40-fold higher protein quantities of the human cancer cell lines were needed to detect similar immune reactivity, like the marmoset monkey GnRH-II receptor, the human tumour GnRH-II receptor-like protein seems to be much less expressed than in the ovaries of marmoset monkeys.

To identify the human GnRH-II receptor-like antigen as a GnRH-II-binding site we used the photo-affinity labelling technique. The photochemical reaction of ${ }^{125}$ I-labelled (4-azidobenzoyl)-N-hydroxysuccinimide[D-Lys ${ }^{6}$ ]-GnRH-II with cell membrane preparations of human endometrial and ovarian cancer cells yielded a band at approximately $43 \mathrm{kDa}$. Using the antiGnRH-II receptor antiserum this band could be identified as a GnRH-II receptor-like antigen.

Since the human ovarian cancer cell line EFO-27 is not affected by GnRH-II we expected this cell line to be GnRH-II receptor negative. However, we detected weak GnRH-II receptor antigenicity. It is possible that the GnRH-II receptor density is too low to detect cellular effects in this cell line. Another possibility is that the GnRH-II receptor-like protein in this cell line is not located within the cell membrane and therefore ligand binding and signalling is not possible. This explanation is supported by the fact that the EFO-27 cell line showed only an extremely weak binding of ${ }^{125}$ I-labelled (4-azidobenzoyl)-N-hydroxysuccinimide[D-Lys ${ }^{6}$ ]-GnRH-II using the photo-affinity labelling technique. The same situation was found for human placenta. We detected GnRH-II receptor antigenicity in human placenta, but extremely weak binding of
${ }^{125}$ I-labelled (4-azidobenzoyl)-N-hydroxysuccinimide[D-Lys ${ }^{6}$ ]-GnRH-II using the photo-affinity labelling technique. A similar situation was found for the GnRH-I receptor in the human endometrial cancer cell line MFE-296 (7). Another explanation could be that the GnRH-II-binding site needs another receptor to produce a functional GnRH-II responsive receptor and this receptor is not present in the EFO-27 cell line.

In competition experiments, a 100-fold excess of the GnRH-I agonist Triptorelin showed a weak decrease of ${ }^{125}$ I-labelled (4-azidobenzoyl)-N-hydroxysuccinimide[D-Lys ${ }^{6}$ ]-GnRH-II $\left(10^{-9} \mathrm{M}\right)$ binding to its binding site. A 100-fold excess of the GnRH-I antagonist Cetrorelix showed a clearly stronger decrease, whereas GnRH-II agonist [D-Lys ${ }^{6}$-GnRH-II $\left(10^{-7} \mathrm{M}\right)$ was the most potent competitor. These data indicated that the GnRH-II receptor-like antigen could be the specific binding site for GnRH-II. However, these data were from cancer cell lines. Since such cancer cell lines are not like human tissues, it is possible that these cancer cell lines could induce a modified GnRH-II receptor with a molecular weight of $43 \mathrm{kDa}$. Unfortunately, it was not possible for us to detect GnRH-II-binding sites in placental membrane. In earlier studies we showed that two types of GnRH-binding sites exist in endometrial and ovarian cancer cells, one of low affinity and high capacity, the other of high affinity and low capacity $(1-3)$. The latter is comparable with the pituitary GnRH-I receptor. The low affinity binding site for the GnRH-I agonist Triptorelin may be the specific GnRH-II-binding site.

In earlier studies we have demonstrated that a functional GnRH-II receptor may exist in human cancers $(6,7)$. GnRH-II has antiproliferative effects on these tumour cells which are significantly greater than those of the superactive GnRH-I agonist Triptorelin (6). The effects of the GnRH-I agonist Triptorelin were abrogated after GnRH-I receptor knockout, whereas those of GnRH-II persisted (8), suggesting that the antiproliferative effects of GnRH-II are not mediated through the GnRH-I receptor. Enomoto et al. (9) found that the splice variants of the human GnRHII receptor determine the direction of the cellular response to GnRH stimulation. Choi et al. (10) demonstrated the expression of the ligand (GnRH-II) in normal neoplastic ovarian surface epithelial cells and in cancers derived from these cells, suggesting the existence of an autocrine system based on GnRH-II in human cancers. Siler-Khodr \& Grayson (24) have reported that in the human placenta the biopotency of GnRH-II on placental hormonogenesis was more than 25-fold higher than that of GnRH-I. In addition, they found that GnRH-II is active in a number of other normal extra-hypothalamic tissues, which is consistent with the widespread expression of the GnRH-II receptor $(24,25)$. These findings indicated that, in addition to the cancers, a GnRH-II system may exist in normal human tissues. 
Several groups have tried to find a functional human GnRH-II receptor transcript (11-14). Van Biljon et al. (26) have recently cloned a GnRH-II receptor transcript from human sperm. This, although containing all the exons required for a full-length receptor protein, contains a stop codon and a frame shift. Although this would suggest that the gene is a transcribed pseudogene, there are several lines of evidence for a functional role of GnRH-II receptor in human sperm and testis (26). Thus, if the gene is not a pseudogene, the transcript could possibly be translated as a truncated, immunoreactive protein or edited to result in translation of a full-length protein, possibly containing selenocysteine. However, given that RNA editing and/or incorporation of selenocysteine are rare events, the latter possibility seems unlikely.

Further investigations are therefore required to identify the receptor that mediates the activities of GnRH-II and to elucidate the entire mechanism of these effects. In addition, it is necessary to generate protein sequence data. Nevertheless, our above-mentioned data suggest that a GnRH-II receptor-like protein exists in human placenta and in cancers of human reproductive organs.

\section{Acknowledgements}

We are grateful to Zentaris for supplying the GnRH-I antagonist Cetrorelix (SB-75) and to Ferring Pharmaceuticals for the gift of the GnRH-I agonist Triptorelin. We thank Renate Dietrich, Matthias Läsche, Cornelia Meiners and Hiltrud Schulz for excellent technical assistance. This work was supported by the GermanIsraeli Foundation for Scientific Research and Development (Grant No. I-684-176.2/2000 to G E) and by the Deutsche Forschungsgemeinschaft (Grant No. GR 1895/2-1 and GR 1895/2-3 to C G).

\section{References}

1 Gründker C, Günthert AR, Westphalen S \& Emons G. Biology of the gonadotropin-releasing hormone (GnRH) system in gynecological cancers. European Journal of Endocrinology 2002146 1-14.

2 Emons G, Ortmann O, Becker M, Irmer G, Springer B, Laun R, Hölzel F, Schulz KD \& Schally AV. High affinity binding and direct antiproliferative effects of LHRH analogues in human ovarian cancer cell lines. Cancer Research 199354 5439-5446.

3 Emons G, Schröder B, Ortmann O, Westphalen S, Schulz KD \& Schally AV. High affinity binding and direct antiproliferative effects of luteinizing hormone-releasing hormone analogs in human endometrial cancer cell lines. Journal of Clinical Endocrinology and Metabolism 199377 1458-1464.

4 Irmer G, Bürger C, Müller R, Ortmann O, Peter U, Kakar SS, Neill JD, Schulz KD \& Emons G. Expression of the messenger RNAs for luteinizing hormone-releasing hormone (LHRH) and its receptor in human ovarian epithelial carcinoma. Cancer Research $1995 \mathbf{5 5} 817-822$.

5 Emons G, Ortmann O, Schulz KD \& Schally AV. Growth-inhibitory actions of luteinizing hormone releasing hormone on tumor cells. Trends in Endocrinology and Metabolism 19978 355-362.
6 Gründker C, Günthert AR, Millar RP \& Emons G. Expression of gonadotropin-releasing hormone II (GnRH-II) receptor in human endometrial and ovarian cancer cells and effects of GnRH-II on tumor cell proliferation. Journal of Clinical Endocrinology and Metabolism 200287 1427-1430.

7 Völker P, Gründker C, Schmidt O, Schulz KD \& Emons G. Expression of receptors for luteinizing hormone-releasing hormone in human ovarian and endometrial cancers: frequency, autoregulation and correlation with direct antiproliferative activity of LHRH analogues. American Journal of Obstetrics and Gynecology 2002186 171-179.

8 Gründker C, Schlotawa L, Viereck V, Eicke N, Horst A, Kairies B \& Emons G. The antiproliferative effects of GnRH antagonist Cetrorelix and of GnRH-II on human endometrial and ovarian cancer cells are not mediated through the GnRH type I (GnRH-I) receptor. European Journal of Endocrinology 2004151 141-149.

9 Enomoto M, Endo D, Kawashima S \& Park MK. Human type II $\mathrm{GnRH}$ receptor mediates effects of $\mathrm{GnRH}$ on cell proliferation. Zoological Science 200421 763-770.

10 Choi KC, Auersperg N \& Leung PCK. Expression and anti-proliferative effect of a second form of gonadotropin-releasing hormone in normal and neoplastic ovarian surface epithelial cells. Journal of Clinical Endocrinology and Metabolism 200186 5075-5078.

11 Millar R, Lowe S, Conklin D, Pawson A, Maudsley S, Troskie B, Ott T, Millar M, Lincoln G, Sellar R, Faurholm B, Scobie G, Kuestner R, Terasawa E \& Katz A. A novel mammalian receptor for the evolutionarily conserved type II GnRH. PNAS $2001 \mathbf{9 8}$ 9636-9641.

12 Millar RP, Conklin D, Lofton-Day C, Hutchinson E, Troskie B, Illing N, Sealfon SC \& Hapgood J. A novel human GnRH receptor homolog gene: abundant and wide tissue distribution of the antisense transcript. Journal of Endocrinology 1999162 117-126.

13 Neill JD, Duck LW, Sellers JC \& Musgrove LC. A gonadotropinreleasing hormone (GnRH) receptor specific for GnRH II in primates. Biochemical and Biophysical Research Communications $20012821012-1018$

14 Neill JD. GnRH and GnRH receptor genes in the human genome. Endocrinology $2002143737-743$.

15 Millar RP. GnRH II and type II GnRH receptors. Trends in Endocrinology and Metabolism 200314 35-43.

16 Morgan K, Conklin D, Pawson AJ, Sellar R, Ott TR \& Millar RP. A transcriptionally active human type II gonadotropin-releasing hormone receptor gene homolog overlaps two genes in the antisense orientation on chromosome 1q.12. Endocrinology 2003 $144423-436$.

17 Hazum E. Photo-affinity inactivation of gonadotropin releasing hormone receptors. FEBS Letters $1981 \mathbf{1 2 8}$ 111-113.

18 Clayton RN, Shakespear RA, Duncan JA, Marshall JC, Munson PJ \& Rodbard D. Radioiodinated nondegradable gonadotropin-releasing hormone analogs: new probes for the investigation of pituitary gonadotropin-releasing hormone receptors. Endocrinology $19791051369-1376$.

19 Laemmli UK. Cleavage of structural proteins during the assembly of the head of bacteriophage T4. Nature $1970 \quad 227$ 680-685.

20 Gault PM, Morgan K, Pawson AJ, Millar RP \& Lincoln GA. Sheep exhibit novel variations in the organization of mammalian type II gonadotropin-releasing hormone receptor gene. Endocrinology $20041452362-2374$.

21 Faurholm B, Millar RP \& Katz AA. The genes encoding the type II gonadotropin-releasing hormone receptor and the ribonucleoprotein RBM8A in humans overlap in two genomic loci. Genomics 200178 15-18.

22 Neill JD, Musgrove LC \& Duck LW. Newly recognized GnRH receptors: function and relative role. Trends in Endocrinology and Metabolism 200415 383-392.

23 Ling K, Wang P, Zhao J, Wu Y-L, Cheng Z-J, Ubi GX, Hu W, Ma L \& Pei G. Five-transmembrane domains appear sufficient for a $G$ protein-coupled receptor: functional five-transmembrane domain chemokine receptors. PNAS $1999967922-7927$. 
24 Siler-Khodr TM \& Grayson M. Action of chicken II GnRH on the human placenta. Journal of Clinical Endocrinology and Metabolism $200186804-810$.

25 Lin XW \& Peter RE. Cloning and expression pattern of a second [His ${ }^{5} \mathrm{Trp}^{7} \mathrm{Tyr}^{8}$ ]gonadotropin-releasing hormone (chicken GnRHII) mRNA in goldfish: evidence for two distinct genes. Genera and Comparative Endocrinology 1997107 262-272.
26 Van Biljon W, Wykes S, Scherer S, Krawetz SA \& Hapgood J. Type II gonadotropin-releasing hormone receptor transcripts in human sperm. Biology of Reproduction 200267 1741-1749.

Received 15 February 2005

Accepted 13 July 2005 